\title{
Iron minerals inhibit the growth of Pseudomonas brassicacearum J12 via a free-radical mechanism: implications for soil carbon storage
}

\author{
Hai-Yan Du ${ }^{1}$, Guang-Hui Yu ${ }^{1,2}$, Fu-Sheng Sun ${ }^{1,2}$, Muhammad Usman ${ }^{3,4}$, Bernard A. Goodman ${ }^{5}$, Wei $\operatorname{Ran}^{1}$, and \\ Qi-Rong Shen ${ }^{1}$ \\ ${ }^{1}$ Jiangsu Provincial Key Lab for Organic Solid Waste Utilization, College of Resources \& Environmental Sciences, \\ Nanjing Agricultural University, Nanjing 210095, China \\ ${ }^{2}$ Institute of Surface-Earth System Science, Tianjin University, Tianjin 300072, China \\ ${ }^{3}$ Environmental Mineralogy, Center for Applied Geosciences, University of Tübingen, 72074 Tübingen, Germany \\ ${ }^{4}$ Institute of Soil and Environmental Sciences, University of Agriculture, Faisalabad 38040, Pakistan \\ ${ }^{5}$ College of Physical Science and Technology, Guangxi University, Nanning 530004, Guangxi, China
}

Correspondence: Guang-Hui Yu (yuguanghui@njau.edu.cn, yuguanghui@ tju.edu.cn)

Received: 13 November 2018 - Discussion started: 10 December 2018

Revised: 5 March 2019 - Accepted: 26 March 2019 - Published: 8 April 2019

\begin{abstract}
Natural minerals in soil can inhibit the growth of bacteria that protect organic carbon from decay. However, the mechanism inhibiting the bacterial growth remains poorly understood. Here, using a series of cultivation experiments and biological, chemical and synchrotron-based spectral analyses, we showed that kaolinite, hematite, goethite and ferrihydrite had a significant inhibitory effect on the growth of the model bacteria Pseudomonas brassicacearum $\mathrm{J} 12$, which was more prominent with a concentration of $25 \mathrm{mg} \mathrm{mL}^{-1}$ than it was with either 10 or $5 \mathrm{mg} \mathrm{mL}^{-1}$. In contrast, montmorillonite promoted the growth of J12. Compared to Al-containing minerals, $\mathrm{Fe}(\mathrm{III})$-containing minerals produced more hydroxyl radical $\left(\mathrm{HO}^{\bullet}\right)$ that has high efficiency for the inhibition of J12. Moreover, a significant positive correlation between $\mathrm{HO}^{\bullet}$ radical and $\mathrm{Fe}(\mathrm{II})$ was found, suggesting that $\mathrm{Fe}(\mathrm{II})$ contributes to the generation of $\mathrm{HO}^{\bullet}$. Furthermore, both micro X-ray fluorescence and X-ray photoelectron spectroscopies indicated that surface Fe(III) was reduced to $\mathrm{Fe}(\mathrm{II})$, which can produce $\mathrm{HO}^{\circ}$ through the wellknown Fenton reaction series. Together, these findings indicate that the reduced surface $\mathrm{Fe}$ (II) derived from $\mathrm{Fe}$ (III)containing minerals inhibits the growth of Pseudomonas brassicacearum $\mathrm{J} 12$ via a free-radical mechanism, which may serve as a ubiquitous mechanism between iron minerals and all of the heterotrophic bacteria in view of taxonom-
\end{abstract}

ically and ecologically diverse heterotrophic bacteria from terrestrial environments as a vast source of superoxide.

\section{Introduction}

A variety of minerals exhibit bacterial inhibition properties by releasing $\mathrm{Al}(\mathrm{III})$ or $\mathrm{Fe}(\mathrm{II})$ (Morrison et al., 2016; McMahon et al., 2016; Williams, 2017). Hence, natural minerals have long been used as bactericidal agents for human pathogens (Williams and Haydel, 2010; Williams et al., 2011). The bacterial inhibition property of a mineral is associated with the particular chemistry and with the mineral properties, resulting in the various bacterial inhibition mechanisms of minerals such as an increase in membrane permeability and oxidative damage (Williams et al., 2008). Iron oxides are abundant in terrestrial and aquatic environments and exist predominantly as ferric minerals such as goethite, ferrihydrite and hematite (Cornell and Schwertmann, 2003; Meunier, 2005; Chesworth, 2008). Due to the ubiquity of soil iron minerals and their distinct inhibition properties, which may affect soil carbon storage and nutrient turnover, investigations of the inhibitory potential of iron minerals on microorganisms are of great importance. 
To better understand the inhibition of bacteria by minerals, the mineral type and size should be examined. Previous studies have demonstrated that $\mathrm{Al}(\mathrm{III})$ - and $\mathrm{Fe}(\mathrm{II})$-containing minerals can inhibit the growth of bacteria (McMahon et al., 2016). For $\mathrm{Al}(\mathrm{III})$-containing minerals, their toxicity mainly depends on the release of $\mathrm{Al}(\mathrm{III})$, an extensively toxic element to bacteria (McMahon et al., 2016). However, Fe(II)containing minerals usually cause oxidative damage to bacteria, i.e., through the oxidative role of reactive oxygen species (ROS), particularly by involving hydroxyl radicals $\left(\mathrm{HO}^{\circ}\right)$ that are generated by an $\mathrm{Fe}(\mathrm{II})$ catalyzed Fenton reaction where $\mathrm{Fe}(\mathrm{II})$ reacts with hydrogen peroxide $\left(\mathrm{H}_{2} \mathrm{O}_{2}\right)$ to form $\mathrm{HO}^{\bullet}$ radicals (Stohs and Bagchi, 1995; Williams et al., 2011; X. Wang et al., 2017; Usman et al., 2018). However, it is unclear whether the common $\mathrm{Fe}$ (III)-containing minerals in soil have a similar inhibition activity with $\mathrm{Al}(\mathrm{III})$ - and $\mathrm{Fe}$ (II)containing minerals.

Taxonomically and ecologically diverse heterotrophic bacteria from terrestrial environments are a vast source of superoxide $\left(\mathrm{O}_{2}^{--}\right)$and $\mathrm{H}_{2} \mathrm{O}_{2}$ (Diaz et al., 2013). Meanwhile, $\mathrm{Fe}(\mathrm{III})$-containing minerals can catalyze the decomposition of $\mathrm{H}_{2} \mathrm{O}_{2}$ to generate strong oxidizing ROS (predominantly $\mathrm{HO}^{\circ}$ radical) through Fenton-like reactions (Eqs. 1-2) (Petigara et al., 2002; Garrido-Ramírez et al., 2010; Georgiou et al., 2015; Usman et al., 2016).

$$
\begin{aligned}
& \equiv \mathrm{Fe}(\mathrm{III})-\mathrm{OH}+\mathrm{H}_{2} \mathrm{O}_{2} \rightarrow \equiv \mathrm{Fe}(\mathrm{II})+\mathrm{H}_{2} \mathrm{O}+\mathrm{HO}_{2}^{\cdot}, \\
& \equiv \mathrm{Fe}(\mathrm{II})+\mathrm{H}_{2} \mathrm{O}_{2} \rightarrow \equiv \mathrm{Fe}(\mathrm{III})-\mathrm{OH}+\mathrm{HO}^{\circ}
\end{aligned}
$$

where $\equiv \mathrm{Fe}(\mathrm{III})-\mathrm{OH}$ represents the iron mineral surface.

These Fenton-like reactions are well known as a type of heterogeneous catalysis (involving Fe minerals), which is distinct from homogeneous Fenton reactions (based on soluble $\mathrm{Fe}(\mathrm{II})$ in acidic media) (Garrido-Ramírez et al., 2010). The major advantage of heterogeneous catalysis is that it operates well over a wide range of $\mathrm{pH}$ values, while homogeneous catalysis displays optimal performance only at a $\mathrm{pH}$ of $\sim 3$ (Garrido-Ramírez et al., 2010). Furthermore, some researchers demonstrated that surface $\mathrm{Fe}(\mathrm{II})$ was generated in the systems of $\mathrm{H}_{2} \mathrm{O}_{2}$ and ferric minerals (Kwan and Voelker, 2003; Polerecky et al., 2012). To date, the impact of $\mathrm{Fe}(\mathrm{III})$-containing minerals on heterotrophic bacteria remains largely unexplored.

Here, we hypothesize that $\mathrm{Fe}$ (III)-containing minerals can inhibit the growth of heterotrophic bacteria through a freeradical mechanism (i.e., Fenton-like reactions). To test our hypothesis, we designed a series of cultivation experiments to monitor the growth of the model bacteria - Pseudomonas brassicacearum $\mathrm{J} 12$ - in the presence of various minerals and in a mineral-free control. Various minerals, including montmorillonite, kaolinite, hematite, goethite and ferrihydrite, were used as the model $\mathrm{Al}(\mathrm{III})$ - or $\mathrm{Fe}$ (III)-containing minerals because they are broadly based in a wide range of soils (Cornell and Schwertmann, 2003; Meunier, 2005; Chesworth, 2008). Specifically, montmorillonite and kaoli- nite are $\mathrm{Al}(\mathrm{III})$-containing minerals, while hematite, goethite and ferrihydrite belong to $\mathrm{Fe}(\mathrm{III})$-containing minerals. Meanwhile, Pseudomonas brassicacearum $\mathrm{J} 12$ was selected as the model heterotrophic bacterium because it represents a major group of rhizobacteria that aggressively colonize plant roots in soils (Zhou et al., 2012). In this study, the objectives were to (1) examine and compare the inhibition properties of $\mathrm{Al}$ and $\mathrm{Fe}$ minerals on $\mathrm{J} 12$; (2) build the correlation between solution chemistry and $\mathrm{HO}^{\circ}$ and the growth of $\mathrm{J} 12$; and (3) identify the mechanism by which $\mathrm{Fe}$ (III)-containing minerals inhibit J12. Throughout our experiments, the $\mathrm{HO}^{\bullet}$ was trapped by terephthalic acid (TPA) (nonfluorescent), and the reaction's fluorescent product, i.e., 2-hydroxylterephthalic acid (HTPA) (Li et al., 2004), was quantitated in a highperformance liquid chromatography (HPLC) system. Correlative micro X-ray fluorescence ( $\mu$-XRF) and synchrotronbased Fourier transform infrared (SR-FTIR) spectroscopies were used to probe the in situ distribution and species of the $\mathrm{Fe}$ and extracellular polymeric substances (EPSs), respectively (Luo et al., 2014; Sun et al., 2017a). X-ray photoelectron spectroscopy (XPS) was also used for analyzing the oxidation state(s) and speciation of Fe (Wilke et al., 2001; Yamashita and Hayes, 2008).

\section{Materials and methods}

\subsection{Mineral preparation}

Five minerals were selected in this study, including kaolinite $\left(\mathrm{Al}_{2} \mathrm{O}_{3} \cdot 2 \mathrm{SiO}_{2} \cdot 2 \mathrm{H}_{2} \mathrm{O}, 98 \%\right.$, Aladdin Reagent Company, Shanghai, China), montmorillonite ( $\left(\mathrm{Al}_{2}\right.$, $\left.\mathrm{Mg}_{3}\right) \mathrm{Si}_{4} \mathrm{O}_{10}(\mathrm{OH})_{2} \cdot n \mathrm{H}_{2} \mathrm{O}, 98 \%$, Aladdin Reagent Company, Shanghai, China) and synthetic hematite, goethite and ferrihydrite. All of the three iron minerals were synthesized by a previously described method (Schwertmann and Cornell, 2007). In brief, ferrihydrite was prepared by dissolving $40 \mathrm{~g} \mathrm{Fe}\left(\mathrm{NO}_{3}\right)_{3} \cdot 9 \mathrm{H}_{2} \mathrm{O}$ in $500 \mathrm{~mL}$ deionized water, and then $330 \mathrm{~mL}$ of $1 \mathrm{M} \mathrm{KOH}$ was added. Goethite was prepared by mixing $180 \mathrm{~mL}$ of $5 \mathrm{M} \mathrm{KOH}$ with $100 \mathrm{~mL}$ of $1 \mathrm{M} \mathrm{Fe}\left(\mathrm{NO}_{3}\right)_{3} \cdot 9 \mathrm{H}_{2} \mathrm{O}$, and then the resulting mixture was aged for $60 \mathrm{~h}$ at $70^{\circ} \mathrm{C}$. Hematite was synthesized by mixing $2 \mathrm{~L}$ of $0.002 \mathrm{M} \mathrm{HNO}_{3}\left(98^{\circ} \mathrm{C}\right)$ with $16.16 \mathrm{~g}$ of $\mathrm{Fe}\left(\mathrm{NO}_{3}\right)_{3} \cdot 9 \mathrm{H}_{2} \mathrm{O}$ and then aging for $7 \mathrm{~d}$ at $98^{\circ} \mathrm{C}$. Once prepared, all three suspensions were dialyzed with deionized water for $3 \mathrm{~d}$ to remove impurity ions, and then the pellets were air-dried. Powder X-ray diffraction (XRD) and FTIR analysis results for the minerals used are shown in Figs. S1S2 in the Supplement. All minerals were crushed and sieved through a $0.149 \mathrm{~mm}$ screen.

\subsection{Pseudomonas cultivation experiments}

The stock strain of $\mathrm{J} 12$ was inoculated in nutrient broth (NB) medium to an optical density $\left(\mathrm{OD}_{600}\right)$ of $\sim 0.6$. The $\mathrm{NB}$ medium includes beef extract $\left(3 \mathrm{~g} \mathrm{~L}^{-1}\right)$, tryptone $\left(5 \mathrm{gL}^{-1}\right)$, 
yeast extract $\left(0.5 \mathrm{~g} \mathrm{~L}^{-1}\right)$ and glucose $\left(10 \mathrm{~g} \mathrm{~L}^{-1}\right)$. The cultivation system contained $9.5 \mathrm{~mL}$ of $\mathrm{NB}$ medium and $0.5 \mathrm{~mL}$ of $\mathrm{J} 12$, with a concentration of minerals of 5,10 or $25 \mathrm{mg} \mathrm{mL}^{-1}$. The final $\mathrm{pH}$ of the cultivation system was adjusted to 7.2. Next, the cultivation media were incubated for $12 \mathrm{~h}$ on a shaking incubator $(180 \mathrm{rpm})$ at $28^{\circ} \mathrm{C}$. Then, $50 \mu \mathrm{L}$ of the cultures were transferred to fresh medium $(10 \mathrm{~mL})$ so that the effects of minerals were negligible. Measurement of the $\mathrm{OD}_{600}$ on mineral suspension was shown in Table $\mathrm{S} 1$ in the Supplement. After $8 \mathrm{~h}$ growth, the growth of J12 was monitored by measuring $\mathrm{OD}_{600}$ of the new culture, and the photographs are shown as Fig. S3. The control experiment was performed without any mineral. All experiments were performed in triplicate. The particle size distribution of the applied raw minerals and the minerals after $12 \mathrm{~h}$ of incubation is listed in Fig. S4. According to the data provided by manufacturers, the specific surface area of kaolinite and montmorillonite are $\sim 40$ and $800 \mathrm{~m}^{2} \mathrm{~g}^{-1}$, respectively. The synthesis of hematite, goethite and ferrihydrite was based on the method from Schwertmann and Cornell (2007), and their specific surface area is approximately $30,20,200$ $300 \mathrm{~m}^{2} \mathrm{~g}^{-1}$, respectively.

\subsection{HPLC analysis}

The $\mathrm{HO}^{\bullet}$ was quantified in an Agilent 1260 Infinity HPLC system (Agilent Technologies, Inc., Germany) equipped with a fluorescence detector (G1321B) and a reverse-phase C18 column (Develosil ODS-UG5, $4.6 \mathrm{~mm} \times 250 \mathrm{~mm}$, Nomura Chemical Co., Japan). The mobile phase consisted of $200 \mathrm{mM} \mathrm{K}_{2} \mathrm{HPO}_{4}$ containing $2 \%$ of $\mathrm{KCl}(\mathrm{pH} 4.37)$ and acetonitrile (90: 10). Standard additions of 0, 0.05, 0.1, 0.5 and 1.0 $\mu \mathrm{M}$ HTPA were used to calibrate the HTPA response in each sample, with a linear response observed for all samples (Fig. S5). All experiments were performed in triplicate.

\subsection{Correlative $\mu$-XRF and SR-FTIR analysis}

After $12 \mathrm{~h}$ growth, the original culture of the $25 \mathrm{mg} \mathrm{mL}^{-1}$ ferrihydrite treatment was frozen at $-20^{\circ} \mathrm{C}$ and directly sectioned without embedding. Then, thin sections $(4 \mu \mathrm{m}$ in thickness) were cut on a cryomicrotome (Cyrotome E, Thermo Shandon Limited, UK) and transferred to infraredreflecting MirrIR Low-E microscope slides (Kevley Technologies, Ohio, USA).

The SR-FTIR analysis was obtained at beamline BL01B1 of the National Center for Protein Science Shanghai (NCPSS). Spectra were recorded in reflectance mode using a Thermo Nicolet 6700 FTIR spectrometer and a continuum infrared microscope with the following settings: aperture size $15 \mu \mathrm{m}$, step size $10 \times 10 \mu \mathrm{m}^{2}$, resolution $4 \mathrm{~cm}^{-1}$ and 64 scans. Spectral maps were processed using Omnic 9.0 (Thermo Fisher Scientific Inc.). After baseline correction, map profiles of $\mathrm{Fe}-\mathrm{OH}, \mathrm{C}-\mathrm{H}, \mathrm{C}=\mathrm{O}, \mathrm{C}-\mathrm{N}$ and $\mathrm{C}-\mathrm{OH}$ were created for peak heights at 3344, 2921, 1632, 1513 and $1030 \mathrm{~cm}^{-1}$, respectively (Sun et al., 2017a, b).

After SR-FTIR analysis, an Fe image was collected at beamline 15U1 of Shanghai Synchrotron Radiation Facility (SSRF) for the same region of the thin section. Fluorescence maps $(\mu$-XRF) of Fe were obtained by scanning the samples under a monochromatic beam at $E=10 \mathrm{keV}$ with a step size of $2.3 \times 3.3 \mu \mathrm{m}^{2}$ and a dwell time of $1 \mathrm{~s}$. Then, two positions were selected for $\mathrm{Fe} \mathrm{K}$-edge $\mu$-X-ray absorption nearedge structure ( $\mu$-XANES) analysis, and $\mu$-XANES spectra were recorded using a $0.1 \mathrm{eV}$ step size with an Si drift detector. Standard samples of hematite, goethite, ferrihydrite, iron(II) oxalate and iron(III) oxalate were recorded in transmission mode. Iron(II) oxalate and iron(III) oxalate represent organic complexing ferrous and ferric, respectively, whereas hematite, goethite and ferrihydrite were used as the main iron mineral species. Linear combination fitting of standards was also performed for the $\mu$-XANES spectra of samples, using ATHENA software (version 2.1.1). A standard was considered to have a substantial contribution if it accounted for more than $10 \%$ of a linear combination fit.

\subsection{XPS analysis}

The species of iron oxides were analyzed by XPS (PHI5000 Versa Probe, ULVAC-PHI, Japan). All the samples were freeze-dried and ground to fine powders prior to the XPS measurement. The XPS spectra were obtained with a monochromatized $\mathrm{Al} \mathrm{K} \alpha \mathrm{X}$-ray source $(1486.6 \mathrm{eV})$ and the pressure in the analytical chamber was below $6 \times 10^{-8} \mathrm{~Pa}$ (Yangzhou University). For wide-scan spectra, an energy range of $0-1100 \mathrm{eV}$ was used with a pass energy of $80 \mathrm{eV}$ and a step size of $1 \mathrm{eV}$. The high-resolution scans were conducted according to the peak being examined with the pass energy of $40 \mathrm{eV}$ and the step size of $0.06 \mathrm{eV}$. The precision of XPS was $0.06 \mathrm{eV}$. In order to obtain the oxidation status of surface sites, narrow scan spectra for $\mathrm{Fe} 2 \mathrm{p}_{3 / 2}$ were acquired. The carbon $1 \mathrm{~s}$ electron binding energy corresponding to graphitic carbon at $284.8 \mathrm{eV}$ was used as a reference for calibration purposes. Narrow scan spectra for $\mathrm{Fe} 2 \mathrm{p}_{3 / 2}$ were collected in binding energy forms and fitted using a least-squares curvefitting program (XPSPEAK41 software). The XPS spectra were analyzed after subtracting the Shirley background that was applied for transition metals. The full width at half maximum of those spectra was fixed constant between 1 and 3 and the percentage of Lorentzian-Gaussian was set at $20 \%$ for all the spectra.

\subsection{Electron paramagnetic resonance (EPR) spectroscopy}

The EPR spectra were recorded with a Bruker A300 Xband spectrometer (Guangxi University), which used a Gunn diode as microwave source and incorporated a highsensitivity cavity. Individual spectra were recorded over scan 
ranges of 500 and $30 \mathrm{mT}$ to observe the signals originating from transition metal ions and free radicals, respectively. Details of additional spectra and all other acquisition parameters are given in the references (Goodman et al., 2016). The $g$ values were calculated by reference with the Bruker ER4119HS-2100 marker accessory which has a $g$ value of 1.9800. Spectral data were processed using the Bruker WinEPR software; with samples recorded with the same values for the microwave power, modulation amplitude, time constant and conversion time; intensities were determined both from double integration of complete spectra after background correction and the heights of individual peaks and corrected for any differences in the receiver gain or number of scans. Simulations of spectra to test the validity of various models for the $\mathrm{C}$-center spectrum were performed using the Bruker SimFonia software.

\subsection{Chemical analysis}

At cultivation time of 2 and $12 \mathrm{~h}$ of the original cultures, portions of the samples were centrifuged at $16000 \mathrm{~g}$ for $5 \mathrm{~min}$, then filtered through a $0.45 \mu \mathrm{m}$ membrane filter and analyzed with inductively coupled plasma-atomic emission spectroscopy (710/715 ICP-AES, Agilent, Australia) to detect the concentration of soluble $\mathrm{Fe}$ and $\mathrm{Al}$. Total $\mathrm{Fe}$ and $\mathrm{Fe}$ (II) were determined with a modified 1,10-phenanthroline method (Amonette, 1998). Turbidity at $600 \mathrm{~nm}$ (a standard proxy for bacterial cell density) was measured using a microplate reader (Hach DR/2010) in mid-exponential phase. The $\mathrm{pH}$ of Pseudomonas brassicacearum $\mathrm{J} 12$ cultivated with different minerals or without mineral (control) was detected after $12 \mathrm{~h}$. Eh of the suspension of minerals alone ( $25 \mathrm{mg} \mathrm{mL}^{-1}$ ) and of a bacteria-mineral mixture was detected by a redox potentiometer (Orion star A211, Thermo Fisher scientific, USA). All experiments were performed in triplicate.

\subsection{Statistical analysis}

Significance was determined using one-way ANOVA followed by Tukey's HSD post hoc test, where the conditions of normality and homogeneity of variance were met; means \pm SE $(n=3)$ that are followed by different letters indicate significant differences between treatments at $p<0.05$. The one sample Kolmogorov-Smirnov test is used to test whether a sample comes from a specific distribution. In this study we used this procedure to determine whether the data set was normally distributed. In the regression equation, the parameters $R$ and $t$ represent the coefficient of determination and the result of the $t$ test. Microsoft Excel (2010), Origin Pro8 and SPSS (18.0) were used for drawing the graphs and data analysis.

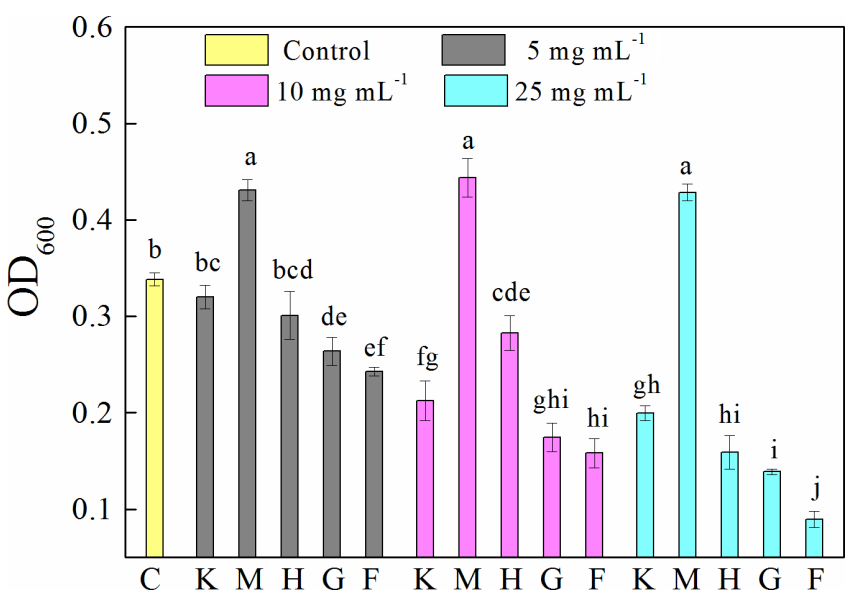

Figure 1. Optical density at $600 \mathrm{~nm}\left(\mathrm{OD}_{600}\right)$ of $8 \mathrm{~h}$ old Pseudomonas brassicacearum $\mathrm{J} 12$ subcultures taken after $12 \mathrm{~h}$ growth with different minerals and with no minerals (control). Alcontaining minerals: $\mathrm{K}$ - kaolinite; $\mathrm{M}$ - montmorillonite. Fecontaining minerals: $\mathrm{H}$ - hematite; $\mathrm{G}$ - goethite; $\mathrm{F}$ - ferrihydrite. $\mathrm{C}$ - control (i.e., no mineral). Gray, magenta and cyan represent mineral concentrations of 5,10 and $25 \mathrm{mg} \mathrm{mL}^{-1}$, respectively. Values are the mean $\pm \operatorname{SE}(n=3)$.

\section{Results}

\subsection{Effect of mineral nature and their concentrations on $\mathbf{J 1 2}$ development}

Compared to the control $(0.34 \pm 0.01)$, the presence of montmorillonite significantly $(p<0.05)$ increased $\mathrm{OD}_{600}$ (Fig. 1). Specifically, the $\mathrm{OD}_{600}$ values of samples were $0.43 \pm 0.01,0.44 \pm 0.02$ and $0.43 \pm 0.01$ at concentrations of 5,10 and $25 \mathrm{mg} \mathrm{mL}^{-1}$, respectively. The presence of all other investigated minerals decreased $\mathrm{OD}_{600}$ in the following order: ferrihydrite $(0.24 \pm 0.04$ and $0.09 \pm$ $0.01)>$ goethite $(0.26 \pm 0.02$ and $0.14 \pm 0.00)>$ hematite $(0.30 \pm 0.03$ and $0.16 \pm 0.02)>$ kaolinite $(0.32 \pm 0.01$ and $0.20 \pm 0.01)$ at 5 and $25 \mathrm{mg} \mathrm{mL}^{-1}$, respectively, and ferrihydrite $(0.16 \pm 0.02)>$ goethite $(0.18 \pm 0.02)>$ kaolinite $(0.21 \pm$ $0.02)>$ hematite $(0.28 \pm 0.02)$ at $10 \mathrm{mg} \mathrm{mL}^{-1}$. An increase in mineral concentration resulted in a significant $(p<0.05)$ decrease in $\mathrm{OD}_{600}$. However, in the presence of montmorillonite the $\mathrm{OD}_{600}$ is stable at about 0.43 for all the mineral concentrations studied.

\subsection{Chemical structure of minerals}

To further explore the factors influencing the bacterial growth by montmorillonite, electron paramagnetic resonance (EPR) spectra were used. The EPR spectra revealed that both the kaolinite and montmorillonite samples were dominated by signals from structural Fe(III), which were located around 1600 gauss $(g \sim 4.3)$ (Fig. 2). Iron oxides, which are commonly associated with these minerals produce a broad signal 


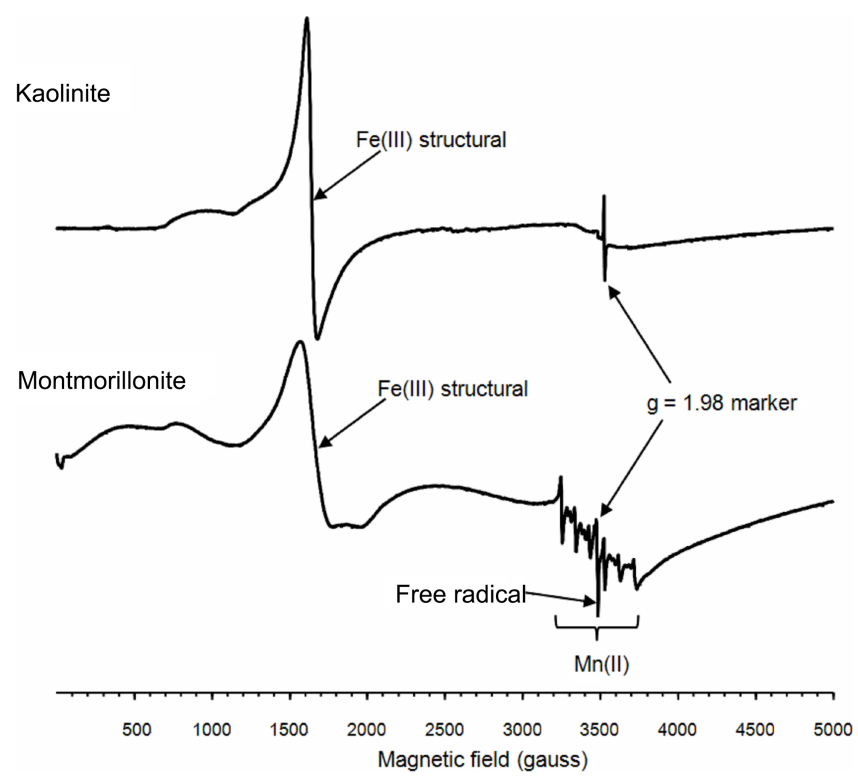

Figure 2. Wide-scan EPR spectra of both the kaolinite and montmorillonite.

centered on $\sim 3500$ gauss $(g \sim 2.0)$. However, the relatively weak resonance indicated that neither sample had appreciable amounts of iron oxides associated with it. The montmorillonite also showed a signal from $\mathrm{Mn}$ (II) and a free radical, whereas the free-radical signal in the kaolinite was very weak, and there was no evidence of any Mn(II) signal in this sample.

\subsection{Generation of $\mathrm{HO}^{\circ}$}

A $12 \mathrm{~h}$ cultivation of $\mathrm{J} 12$ in the presence of different minerals revealed that the generation of $\mathrm{HO}^{*}$ radicals in the cases of montmorillonite, kaolinite and hematite was similar $(p>0.05)$ to the control at low concentrations (i.e., $\left.5 \mathrm{mg} \mathrm{mL}^{-1}\right)$ but significantly different $(p<0.05)$ at high concentrations (i.e., $25 \mathrm{mg} \mathrm{mL}^{-1}$ ) (Fig. 3). However, the presence of goethite and ferrihydrite significantly increased the production of $\mathrm{HO}^{\bullet}$ radicals, which increased with an increase in their concentration. Specifically, in ferrihydrite treatments, the concentration of $\mathrm{HO}^{-}$was approximately $260 \mathrm{nM}$ at 5 and $10 \mathrm{mg} \mathrm{mL}^{-1}$ but increased significantly to $450 \mathrm{nM}$ at $25 \mathrm{mg} \mathrm{mL}^{-1}$. In addition, the generation of $\mathrm{HO}^{*}$ at early growth (i.e., $2 \mathrm{~h}$ ) was only detected with ferrihydrite at both 10 and $25 \mathrm{mg} \mathrm{mL}^{-1}$ and with goethite at $25 \mathrm{mg} \mathrm{mL}^{-1}$ (Fig. S6).

\subsection{Iron chemistry and its correlation with $\mathrm{HO}^{\circ}$ and OD $_{600}$}

To explore the factors affecting the generation of $\mathrm{HO}^{\circ}$ and the inhibition of $\mathrm{J} 12$, we examined iron chemistry and its correlation with $\mathrm{HO}^{\bullet}$ and $\mathrm{OD}_{600}$ (Fig. 5). Much more soluble Fe at $12 \mathrm{~h}$ was released from $\mathrm{Fe}(\mathrm{III})$-containing miner-

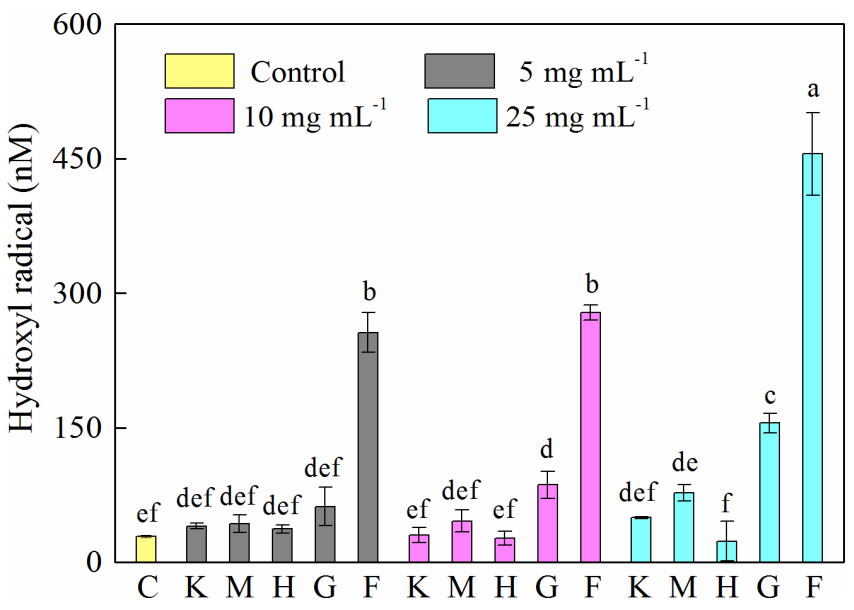

Figure 3. Generation of hydroxyl radical $\left(\mathrm{HO}^{\bullet}\right)$ after $12 \mathrm{~h}$ growth of Pseudomonas brassicacearum $\mathrm{J} 12$ with different minerals and with no minerals (control). Al-containing minerals: $\mathrm{K}$ - kaolinite; $\mathrm{M}$ - montmorillonite. Fe-containing minerals: $\mathrm{H}$ - hematite; $\mathrm{G}$ - goethite; F - ferrihydrite. C - control (i.e., no mineral). Gray, magenta and cyan represent mineral concentrations of 5, 10 and $25 \mathrm{mg} \mathrm{mL}^{-1}$, respectively. Values are the mean $\pm \mathrm{SE}(n=3)$.

als (6.7-27, 21-36 and 41-107 $\mathrm{mg} \mathrm{L}^{-1}$ for hematite, goethite and ferrihydrite, respectively) than from montmorillonite $(\sim$ $\left.0.3 \mathrm{mg} \mathrm{L}^{-1}\right)$, kaolinite $\left(\sim 0.6 \mathrm{mg} \mathrm{L}^{-1}\right)$ and the control $(\sim$ $0.4 \mathrm{mg} \mathrm{L}^{-1}$ ) (Fig. 5a). With the increase in concentration, soluble Fe significantly $(p<0.05)$ increased at both 2 and $12 \mathrm{~h}$ for the ferrihydrite and only at $12 \mathrm{~h}$ for goethite. As for hematite, a significant $(p<0.05)$ increase was only observed from 5 to $10 \mathrm{mg} \mathrm{L}^{-1}$ at $12 \mathrm{~h}$ (Fig. S7). The solubility of $\mathrm{Fe}$ was closely related to redox potential and $\mathrm{pH}$ value (Fig. S8). Results showed that the Eh of a bacteriamineral mixture after incubation was generally lower than the suspension of minerals alone (Table S5), suggesting that the redox potential was decreased by the interaction between mineral and J12. Furthermore, the solution $\mathrm{pH}$ was determined after $12 \mathrm{~h}$ growth of $\mathrm{J} 12$ with different minerals and with no minerals (control) (Fig. 4). The range of solution $\mathrm{pH}$ varied from 4 to 6 for all of the treatments, except for ferrihydrite treatment with a $\mathrm{pH}$ near 7 . For all of the examined minerals, the trends at $12 \mathrm{~h}$ were similar in the following order (total $\mathrm{Fe}$ and $\mathrm{Fe}(\mathrm{II})$ ): ferrihydrite $\left(760-3588\right.$ and $\left.182-488 \mathrm{mg} \mathrm{L}^{-1}\right)>$ goethite $(48$ 127 and 31-94 $\mathrm{mg} \mathrm{L}^{-1}$ ) > hematite (15-82 and 9-35 $\mathrm{mg} \mathrm{L}^{-1}$ ) $>$ montmorillonite (5-10 and 4-8 $\left.\mathrm{mg} \mathrm{L}^{-1}\right)$, kaolinite (10-12 and $4-9 \mathrm{mg} \mathrm{L}^{-1}$ ) or control (7 and $6 \mathrm{mg} \mathrm{L}^{-1}$ ) (Fig. 5b, c). A significant difference in total $\mathrm{Fe}$ in solutions containing $25 \mathrm{mg} \mathrm{mL}^{-1}$ ferrihydrite between 2 and $12 \mathrm{~h}$ may be attributable to the aging of a portion of ferrihydrite to its more crystalline counterparts, as revealed by $\mu$-XRF, which could not be dissolved by the modified 1,10-phenanthroline method. 


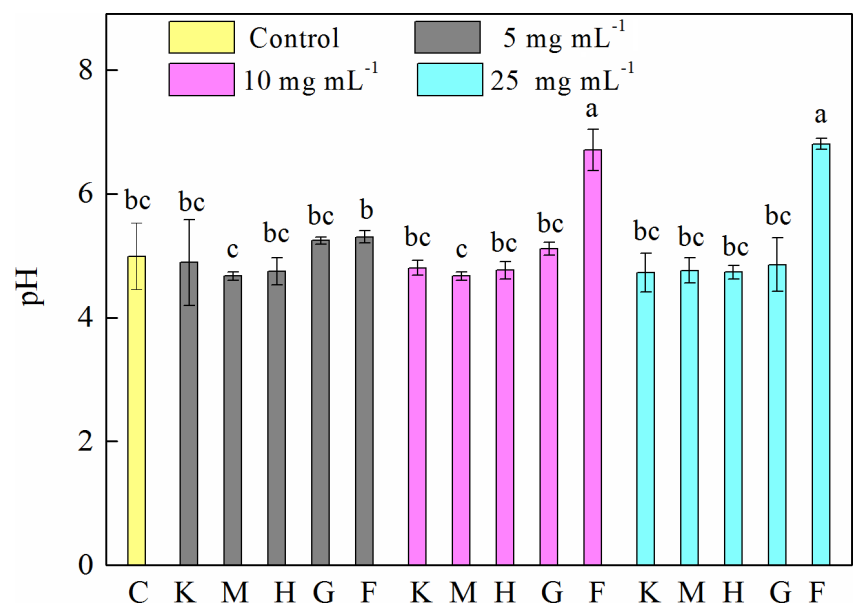

Figure 4. Determination of $\mathrm{pH}$ after $12 \mathrm{~h}$ growth of Pseudomonas brassicacearum $\mathrm{J} 12$ with different minerals and with no minerals (control). Al-containing minerals: $\mathrm{K}$ - kaolinite; $\mathrm{M}$ - montmorillonite. Fe-containing minerals: $\mathrm{H}$ - hematite; $\mathrm{G}$ - goethite; $\mathrm{F}$ - ferrihydrite. $\mathrm{C}$ - control (i.e., no mineral). Gray, magenta and cyan represent mineral concentrations of 5,10 and $25 \mathrm{mg} \mathrm{mL}^{-1}$, respectively. Values are the mean $\pm \operatorname{SE}(n=3)$.

Furthermore, a positive correlation exists between $\mathrm{HO}^{*}$ and soluble Fe content $(R=0.92, t=-3.49, p=0.003)$ and $\mathrm{Fe}$ (II) $(R=0.98, t=-4.28, p=0.001)$ (Fig. 5d and $\mathrm{f}$, Table S2). However, a significant but negative correlation between $\mathrm{OD}_{600}$ and soluble $\mathrm{Fe}(R=-0.57, t=2.99$, $p=0.009)$ and $\mathrm{Fe}(\mathrm{II})(R=-0.81, t=2.23, p=0.038)$ was found (Fig. $5 \mathrm{~g}$ and i). Moreover, the correlation between $\mathrm{HO}^{\bullet}$ and $\mathrm{Fe}(\mathrm{III})(R=0.94, t=1.38, p=0.19)$ and between $\mathrm{OD}_{600}$ and $\mathrm{Fe}$ (III) $(R=-0.80, t=1.67, p=0.116)$ were not significant (Fig. 5e and h). To test whether the release of Fe(III) to solution inhibits the growth of J12 via a freeradical mechanism, we replaced $\mathrm{Fe}(\mathrm{III})$-containing minerals by adding a series of concentrations of $\mathrm{Fe}\left(\mathrm{NO}_{3}\right)_{3}$, i.e., 0,50 and $100 \mathrm{mg} \mathrm{L}^{-1}$, to the cultivation experiments with the final $\mathrm{pH}$ of 7.2. The results showed that addition of $\mathrm{Fe}(\mathrm{III})$ can inhibit the growth of $\mathrm{J} 12(25 \%-50 \%)$ by producing an additional $\mathrm{HO}^{*}$ concentration of $15 \mathrm{nM}$ (Fig. S9), supporting the role of $\mathrm{Fe}$ (III) ions from solution in the initialization of a free-radical reaction. In addition, the inhibition of soluble $\mathrm{Fe}$ on $\mathrm{J} 12$ was more important in the concentration of $100 \mathrm{mg} \mathrm{L}^{-1}$ than in that of $50 \mathrm{mg} \mathrm{L}^{-1}$ while $\mathrm{HO}^{\bullet}$ production still kept the same between those two concentrations (Fig. S9). The reason for this phenomenon may attributable to the intracellular oxidative damage of soluble Fe that penetrated into cells, triggering intracellular ROS generation.

In addition, we also examined soluble $\mathrm{Al}$ during the cultivation experiments (Fig. 6a) and found a high concentration of $\mathrm{Al}$ in the montmorillonite and kaolinite solutions. However, almost no correlation was found between soluble $\mathrm{Al}$ and $\mathrm{HO}^{\bullet}(R=-0.35, t=-3.36, p=0.004)$ and $\mathrm{OD}_{600}$ $(R=0.30, t=2.24, p=0.041)$ (Fig. 6b, c).

\subsection{In situ observation of Fe species and the distribution of organic functional groups}

To explore the critical role of Fe chemistry in the inhibition of the growth of J12, we used correlative $\mu$-XRF and SRFTIR analyses for in situ measurement of the distribution of Fe species and EPS on the surface of ferrihydrite. The $\mu$-XRF spectromicroscopy showed a distinct density of $\mathrm{Fe}$ distributed on iron particles (Fig. 7a). Two positions were selected for identifying the coordination state and species of Fe by $\mu$-XANES spectra. Using hematite, goethite, ferrihydrite, iron(II) oxalate and iron(III) oxalate as reference compounds, the linear combination fitting (LCF) results from Fe K-edge $\mu$-XANES spectra indicated that ferrihydrite was dominant $(\sim 82 \%)$, with a lower percentage $(\sim 17 \%)$ of $\mathrm{FeC}_{2} \mathrm{O}_{4}$ among the mineral particles (A in Fig. $7 \mathrm{~b}$ and Table S3). However, considerable percentages of hematite $(\sim 13 \%)$, goethite $(\sim 19 \%)$ and $\mathrm{FeC}_{2} \mathrm{O}_{4}(\sim 25.9 \%)$ were present on the edge of these mineral particles (B in Fig. 7b and Table S3).

Furthermore, the SR-FTIR spectromicroscopy (Fig. 7c) showed that ferrihydrite $\left(\mathrm{Fe}-\mathrm{OH}, 3344 \mathrm{~cm}^{-1}\right)$ had a similar distribution pattern with lipid $\left(\mathrm{C}-\mathrm{H}, 2921 \mathrm{~cm}^{-1}\right)$, amide $\mathrm{I}\left(\mathrm{C}=\mathrm{O}, 1632 \mathrm{~cm}^{-1}\right)$ and amide II $\left(\mathrm{C}-\mathrm{N}, 1513 \mathrm{~cm}^{-1}\right)$. However, polysaccharides $\left(\mathrm{C}-\mathrm{OH}, 1030 \mathrm{~cm}^{-1}\right)$ seemed to be distributed only in the big mineral particles. Furthermore, correlation analysis confirmed significant $(R \geq 0.68, p<0.003)$ linear correlations between ferrihydrite and these EPSs (i.e., lipid, amide I, amide II and polysaccharides) (Fig. S10).

\subsection{Effect of the presence of J12 on surface Fe species}

XPS analysis was conducted to investigate the oxidation state of Fe in the interface between iron minerals and J12 (Fig. 8). The shift in the Fe $2 \mathrm{p}_{3 / 2}$ peak of $0.5 \mathrm{eV}$ was observed between raw ferrihydrite and ferrihydrite after $12 \mathrm{~h}$ of cultivation with bacteria (Fig. 8a). Four Fe $2 \mathrm{p}_{3 / 2}$ peaks at 709.5 , $710.3,711.5$ and $713.1 \mathrm{eV}$ appeared in the $F+$ bacteria treatment (Fig. 8b, c). The peaks at 710.3, 711.5 and $713.1 \mathrm{eV}$ are regarded as multiplet peaks of Fe(III), but the peak at $709.5 \mathrm{eV}$ is interpreted as Fe(II) (Grosvenor et al., 2004). Interestingly, the area of the peak at $709.5 \mathrm{eV}$ was bigger in the $F+$ bacteria treatment than that in $F$-bacteria treatment (Fig. 8b, c). Based on the Eq. (1), $\mathrm{HO}_{2}^{*}$ should be the oxidant products.

\section{Discussion}

\subsection{Effect of $\mathrm{Al}(\mathrm{III})$-containing minerals on the inhibition of $\mathrm{J12}$ growth}

Our results showed that kaolinite (1:1 layer type) resulted in significant inhibition of the growth of J12, but montmorillonite (2:1 layer-type) remarkably accelerated its growth (Fig. 1). Similarly, recent studies have shown the toxic ef- 

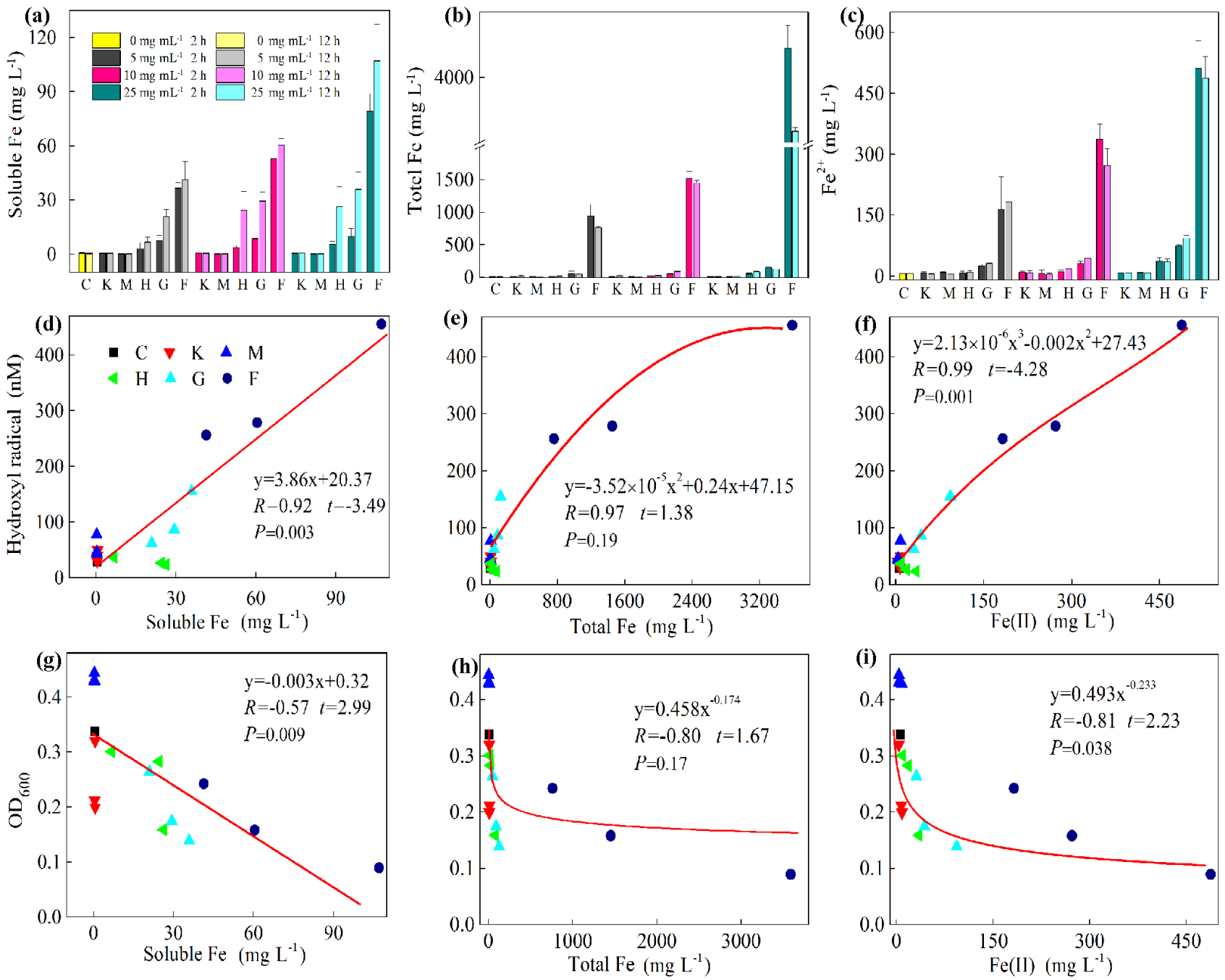

Figure 5. Iron chemistry $(\mathbf{a}-\mathbf{c})$ and its correlation with hydroxyl radical $\left(\mathrm{HO}^{\bullet}\right)(\mathbf{d}-\mathbf{f})$ as well as optical density at $600 \mathrm{~nm}\left(\mathrm{OD}_{600}\right)(\mathbf{g}-\mathbf{i})$. $(\mathbf{a})$ Soluble Fe, (b) total Fe, (c) Fe(II), (d) soluble Fe vs. $\mathrm{HO}^{\bullet}$, (e) total Fe vs. HO, (f) Fe(II) vs. HO, (g) soluble Fe vs. OD 600 , (h) total Fe vs. $\mathrm{OD}_{600}$, (i) $\mathrm{Fe}(\mathrm{II})$ vs. $\mathrm{OD}_{600}$. Al-containing minerals: $\mathrm{K}$ - kaolinite; $\mathrm{M}$ - montmorillonite. Fe-containing minerals: $\mathrm{H}$ - hematite; $\mathrm{G}$ goethite; $\mathrm{F}$ - ferrihydrite. $\mathrm{C}$ - control (i.e., no mineral). Values in (a)-(c) are the mean $\pm \mathrm{SE}(n=3)$.

fects of aluminosilicate on microorganisms (Liu et al., 2016; Wilson and Butterfield, 2014), but bacterial activity was not inhibited by the interfacial interactions between montmorillonite and bacteria (Wilson and Butterfield, 2014). It should be noted that the presence of minerals may potentially interfere with the measurement of cell numbers in Fig. 1. In this study, we subsampled the experimental cultures and diluted them in fresh medium so that both clay particles and J12 were $200 \times$ less concentrated (Fig. S3), following the protocol of McMahon et al. (2016). As a result, the effect of mineral concentration may be minimal. In addition, plating the bacteria by evaluating populations by counting colonies may act as a complementary method for $\mathrm{OD}_{600}$ and needs to be investigated in the future. Furthermore, the association of a cell labeling with 4,6-diamidino-2-phenylindole (DAPI) and a count of labeled cells with flow cytometry (or fluorescence microscopy) is also an alternative choice.

It is generally accepted that diverse bacteria are susceptible to $\mathrm{Al}(\mathrm{III})$. In the present study, the amount of aqueous $\mathrm{Al}$ (III) exceeded $2 \mathrm{mg} \mathrm{L}^{-1}$ for all kaolinite experiments while its concentration was negligible in the presence of montmorillonite during the early growth of J12 (Fig. 6). It is worth noting that $>2 \mathrm{mg} \mathrm{L}^{-1}$ of aqueous $\mathrm{Al}$ (III) was detected for montmorillonite experiments with the passage of time (Fig. 6); however, the growth of J12 was not inhibited (Fig. 1). This may be attributed to the adsorption of aqueous Al(III) by bacterial EPS, which further protected bacteria from damage (Wu et al., 2014). However, direct evidence is lacking in this study and thus further investigation is needed to address this issue. Thus, the inhibition of bacterial activity by kaolinite may possibly be attributed to the 

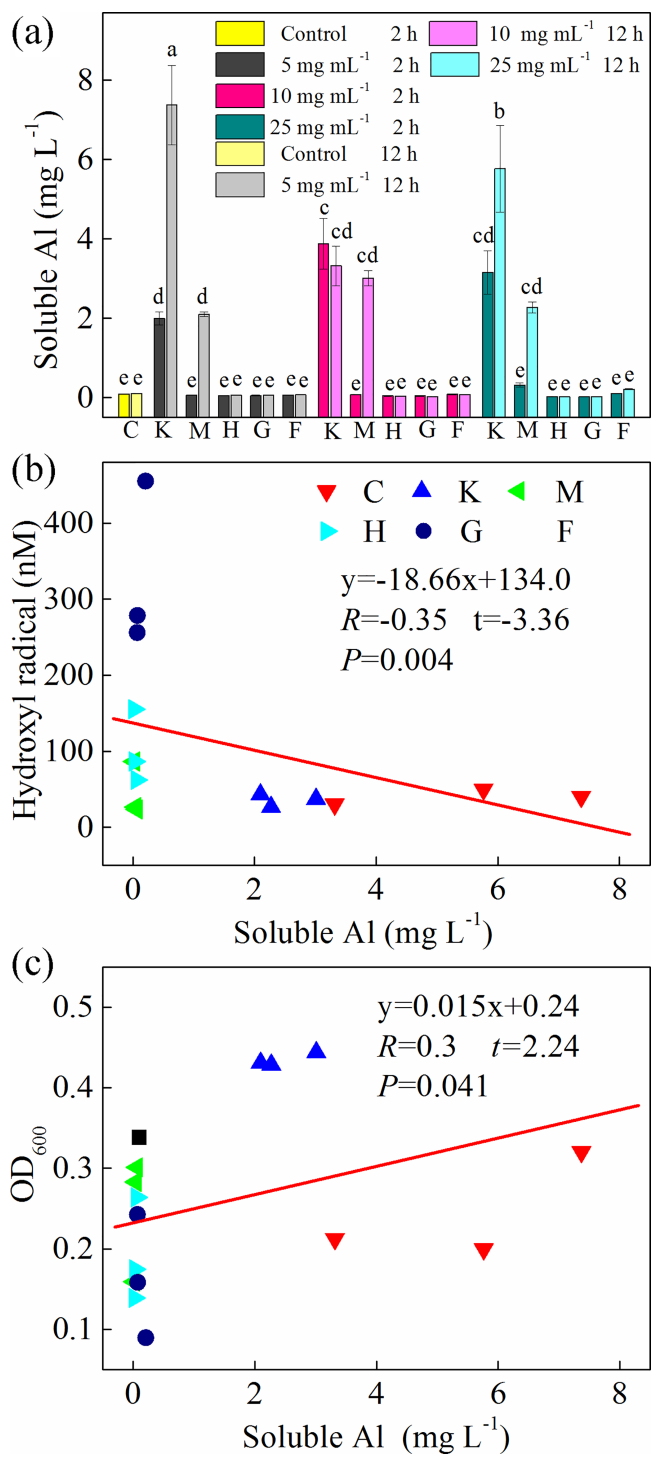

Figure 6. (a) Production of soluble $\mathrm{Al}$ after $2 \mathrm{~h}$ and $12 \mathrm{~h}$ cultivation. Al-containing minerals: $\mathrm{K}$ - kaolinite; $\mathrm{M}$ - montmorillonite. Fecontaining minerals: $\mathrm{H}$ - hematite; $\mathrm{G}$ - goethite; $\mathrm{F}$ - ferrihydrite. $\mathrm{C}$ : control, no minerals. Values in (a) are the mean $\pm \mathrm{SE}(n=3)$. Correlation analysis between $\mathrm{HO}^{\bullet}$ concentration and soluble $\mathrm{Al}$ is shown in (b), and correlation analysis between $\mathrm{OD}_{600}$ and soluble $\mathrm{Al}$ is shown in (c).

toxicity of aqueous $\mathrm{Al}(\mathrm{III})$. Specifically, $\mathrm{Al}(\mathrm{III})$ reacts with membrane phospholipids and then increases membrane permeability that leads to the inactivation of bacteria (Londono et al., 2017).

In addition, some essential elements (e.g., $\mathrm{Mg}$ and $\mathrm{P}$ ) can be affected by Al(III) for bacterial absorption, which could also limit bacterial growth (Piña and Cervantes, 1996; Londono et al., 2017). Furthermore, the formation of some $\mathrm{Al}$ intermediates by the decreasing $\mathrm{pH}$, such as $\mathrm{Al}_{13} \mathrm{O}_{4}(\mathrm{OH})_{24}^{7+}$, is also suggested to be more toxic for bacterial growth (Amonette et al., 2003; Liu et al., 2016). However, we did not detect a significant decrease in $\mathrm{pH}$ in this study (Fig. 4), suggesting that the formation of some $\mathrm{Al}$ intermediates may be slightly.

\subsection{Inhibition of $\mathrm{J12}$ by $\mathrm{Fe}(\mathrm{III})$-containing minerals via a free-radical mechanism}

Our results showed that $\mathrm{Fe}(\mathrm{III})$-containing minerals resulted in higher generation of $\mathrm{HO}^{-}$and had a higher inhibition efficiency on $\mathrm{J} 12$ than $\mathrm{Al}(\mathrm{III})$-containing minerals (Figs. 1 and 3). Fe is widely known as a transition metal that might cause microbial inactivation through ROS-mediated cellular damage, i.e., genotoxicity, protein dysfunction and impaired membrane function (Lemire et al., 2013). Inhibition of heterotrophic bacteria by $\mathrm{Fe}$ minerals is generally attributed to the generation of $\mathrm{HO}^{*}$ through a Fenton reaction (Morrison et al., 2016) or Fenton-like reaction (Garrido-Ramírez et al., 2010). Due to its amorphous structure, high reactive surface area and solubility, ferrihydrite $\left(\sim 200-300 \mathrm{~m}^{2} \mathrm{~g}^{-1}\right)$ is more likely to physically interact with bacterial surfaces than hematite $\left(\sim 30 \mathrm{~m}^{2} \mathrm{~g}^{-1}\right)$ and goethite $\left(\sim 20 \mathrm{~m}^{2} \mathrm{~g}^{-1}\right)$ (Schwertmann and Cornell, 2007; Lemire et al., 2013). A recent study demonstrated that metal oxide nanoparticles produced more ROS than bulk metal oxides (X. Wang et al., 2017). In this study, we observed higher $\mathrm{HO}^{\bullet}$ formation and stronger inhibition of J12 in ferrihydrite treatments (Figs. 1 and 3), suggesting that reactive surface area and solubility have a significant effect on enhancing formation of $\mathrm{HO}^{\bullet}$ and inhibition activity of J12. Reactive mineral surfaces can catalyze $\mathrm{HO}^{*}$ generation or act as "carriers" where $\mathrm{HO}^{\circ}$-inducing materials are adsorbed (Schoonen et al., 2006). In our experiment, there was a smaller amount of $\mathrm{HO}^{\bullet}$ produced with the different concentrations of aqueous $\mathrm{Fe}\left(\mathrm{NO}_{3}\right)_{3}$ (Fig. S9) than with the iron minerals (Fig. 3), which was in line with other studies (Kwan and Voelker, 2003; D. Wang et al., 2017). Therefore, we deduced that $\mathrm{HO}^{\bullet}$ may mainly be generated on the mineral surface, partly due to the positive charge of mineral surface (Tombácz and Szekeres, 2006) but the negative charge of microbes (Jucket et al., 1996).

A recent study demonstrated that surface rather than aqueous $\mathrm{Fe}(\mathrm{II})$ plays a dominant role in producing extracellular $\mathrm{HO}^{\bullet}$ that damages cell membrane lipid as revealed by in situ imaging (D. Wang et al., 2017). The following reactions (Eqs. 3-4) reveal that the generation of $\mathrm{HO}^{*}$ is catalyzed by surface Fe(II) (Kwan and Voelker, 2003; Polerecky et al., 2012):

$$
\begin{aligned}
& \equiv \mathrm{Fe}(\mathrm{III})+\mathrm{H}_{2} \mathrm{O}_{2} \rightarrow \equiv \mathrm{Fe}(\mathrm{II})+\mathrm{H}^{+}+\mathrm{HO}_{2}^{\cdot}, \\
& \equiv \mathrm{Fe}(\mathrm{II})+\mathrm{H}_{2} \mathrm{O}_{2} \rightarrow \equiv \mathrm{Fe}(\mathrm{III})+\mathrm{HO}^{\bullet}+\mathrm{OH}^{-} .
\end{aligned}
$$

In this study, a substantial amount of $\mathrm{Fe}(\mathrm{II})$ was generated by ferrihydrite, approximately 4 times higher than soluble Fe (Fig. 5). This amount of Fe(II) included two portions: one existed in solution; another was derived from the mineral surface. To further confirm the generation of surface $\mathrm{Fe}(\mathrm{II}), \mathrm{Fe}$ K-edge $\mu$-XANES analysis was used, and it showed that ferrihydrite presented various $\mathrm{Fe}$ species, and $\mathrm{Fe}(\mathrm{II})$ increased 
(a)

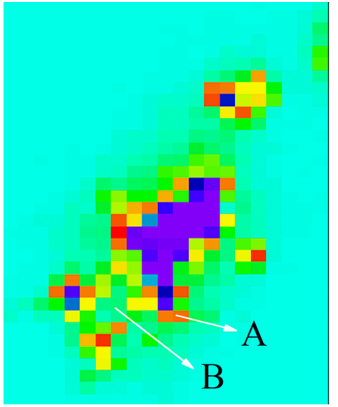

(c)

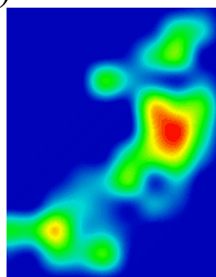

$\mathrm{Fe}-\mathrm{OH}$

$3344 \mathrm{~cm}^{-1}$ (b)
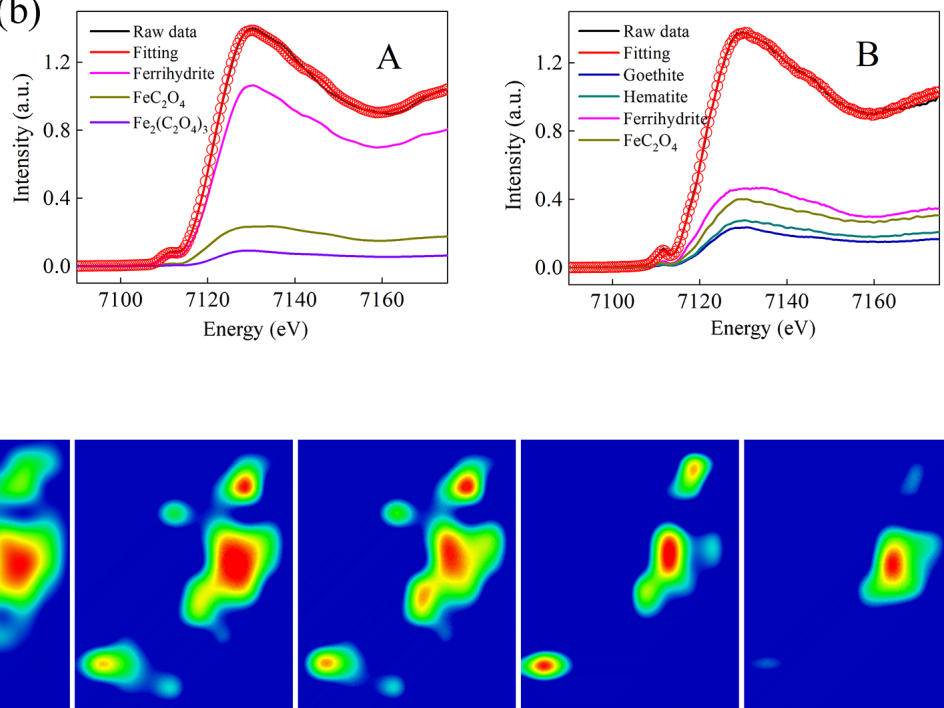

$\mathrm{C}-\mathrm{O}$

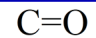

$\mathrm{C}-\mathrm{H}$

$1632 \mathrm{~cm}^{-1}$
C-N

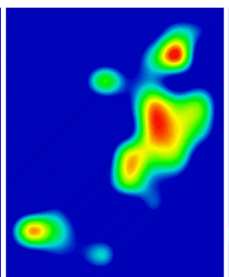

$1513 \mathrm{~cm}^{-1}$
$1230 \mathrm{~cm}^{-1}$

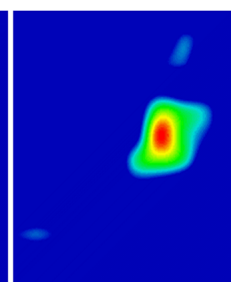

$\mathrm{C}-\mathrm{OH}$

$1030 \mathrm{~cm}^{-1}$

Figure 7. Correlative micro X-ray fluorescence ( $\mu$-XRF) and synchrotron-based Fourier transform infrared (SR-FTIR) analysis of the thin section from the cultures of the $25 \mathrm{mg} \mathrm{mL}^{-1}$ ferrihydrite treatment after $12 \mathrm{~h}$ cultivation. (a) $\mu$-XRF map. (b) The LCF fitting of $\mu$-X-ray absorption near-edge structure (XANES) analysis in the selected regions of interest (ROI) region (i.e., A and B). (c) SR-FTIR maps. Red color in (a) represents high density of Fe, followed by orange, yellow, green, light green and purple.The color scale in (c) is a relative scale for each peak height and does not allow quantitative comparisons between peaks.
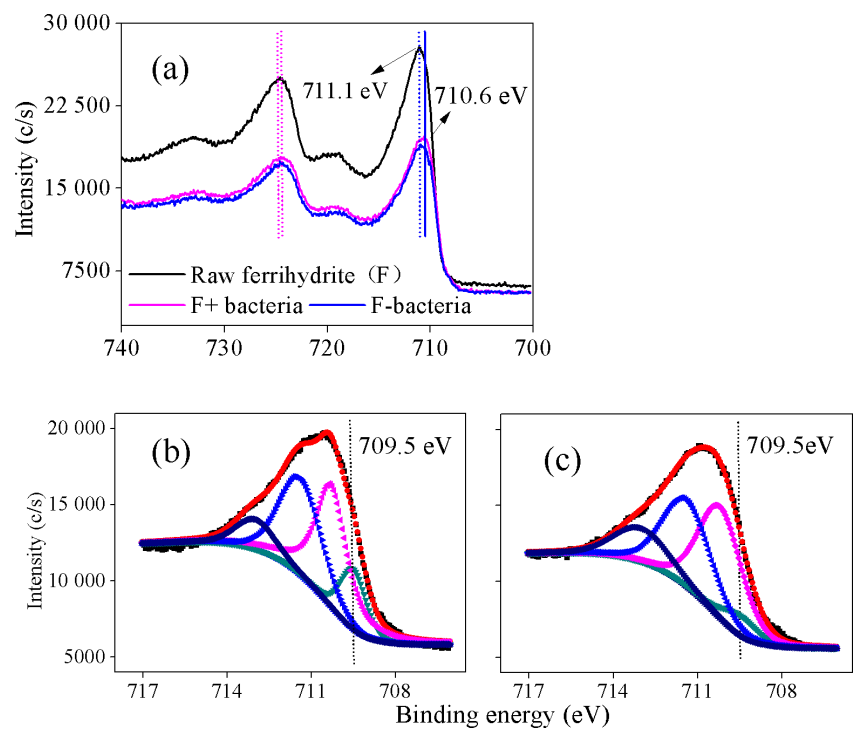

Figure 8. (a) Fe $2 \mathrm{p}$ X-ray photoelectron spectroscopy (XPS) spectra of ferrihydrite samples, $F+$ bacteria and $F$ - bacteria; (bc) $\mathrm{Fe} 2 \mathrm{p}_{3 / 2}$ spectra of $F+$ bacteria and $F$ - bacteria, respectively, during the cultivation $(12 \mathrm{~h}) . F+$ bacteria: ferrihydrite with bacteria; $F$ - bacteria: ferrihydrite without bacteria. In panels (b) and (c), dark, orange and other lines represents the raw spectrum, fitted spectrum and the component of fitted Fe species. from $17.3 \%$ among the mineral particles (A position) to $25.9 \%$ at the edge of mineral particles (B position) (Fig. 7 and Table S3). A high percentage of the less stable ferrihydrite (Table S3) may be attributable to the stabilizing role of EPS (Fig. 7c) produced by J12. It is consistent with a previous finding in the cultivation of fungi with minerals (Li et al., 2016). The stabilizing role of EPS on metastable ferrihydrite was mainly identified as its incorporation into the network structure of minerals, which prevents the formation of crystalline minerals (Braunschweig et al., 2013). Note that the LCF results are dependent on the range of compounds used to generate the reference spectrum library, which is one drawback of LCF. To further support the LCF results, XPS, being a near-surface sensitive technique, is also used to detect the production of ferrous iron at the surface of the iron oxides, owing to a greater certainty than with LCF and XANES to demonstrate the presence of ferrous iron by fitting multipletsplitting models (Grosvenor et al., 2004). According to the XPS analysis, the Fe $2 \mathrm{p}_{3 / 2}$ peak shifted from high energy ( $F$ - bacteria) to low energy $(F+$ bacteria) (Fig. 8$)$, revealing that $\mathrm{Fe}(\mathrm{II})$ was produced on the surface of ferrihydrite during cultivation.

In addition to Fenton-like reactions (Garrido-Ramírez et al., 2010), Fe(II) can also be generated by catalyzing a series of intracellular reductants (e.g., glutathione, $\mathrm{NAD}(\mathrm{P}) \mathrm{H}$, L-cysteine and $\mathrm{FADH}_{2}$ ) (Imlay, 2003). Other metabolically formed oxidants released by bacteria may also contribute to 

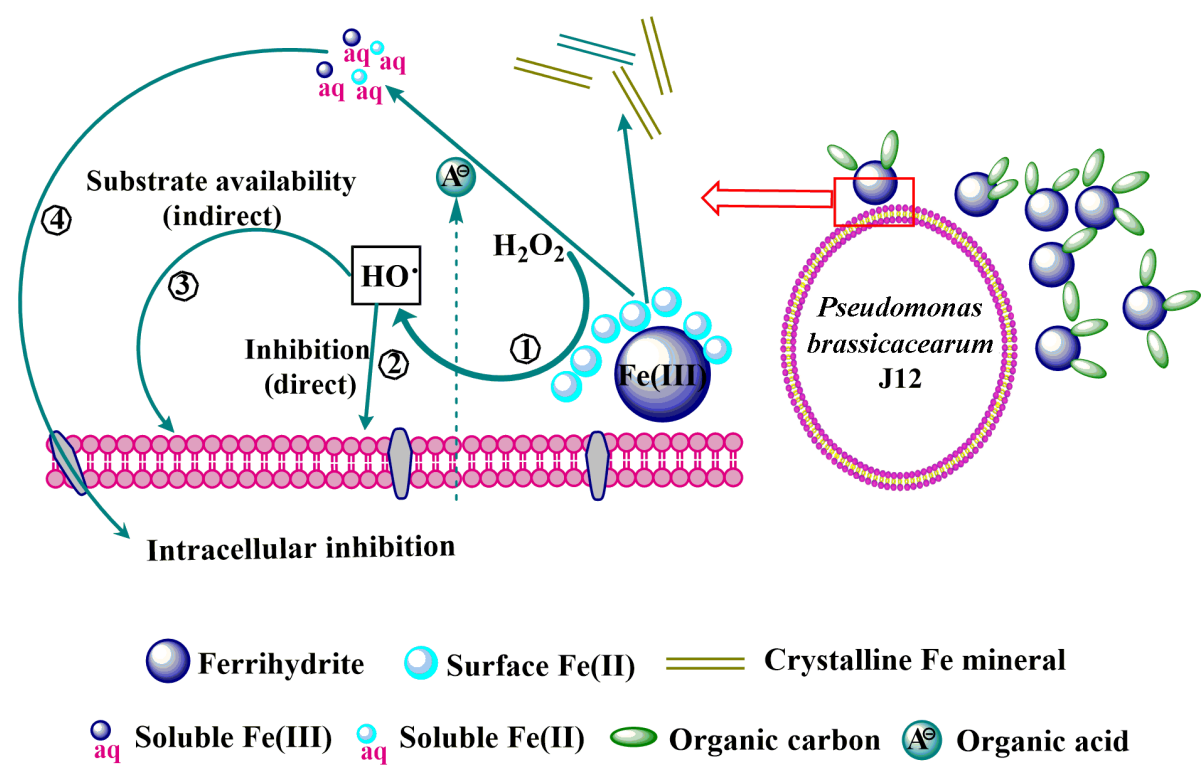

Figure 9. Schematic of the inhibition of heterotrophic bacteria by Fe(III)-containing minerals through a free-radical mechanism. (1)-(4) represent the processes occurring at heterotrophic bacterial-mineral interfaces and are detailed in the main text. (1) Production of $\mathrm{HO}^{\bullet}$ through the Fenton or Fenton-like reactions; (2) direct inhibition of heterotrophic bacteria by $\mathrm{HO}^{\bullet}$; (3) indirect inhibition of heterotrophic bacteria by $\mathrm{HO}^{\bullet}$; (4) intracellular inhibition of heterotrophic bacteria by soluble Fe.

Fe(II) oxidation (Melton et al., 2014). Subsequently, the oxidation of $\mathrm{Fe}$ (II) to $\mathrm{Fe}$ (III) is followed by a reduction of $\mathrm{Fe}$ (III) to $\mathrm{Fe}(\mathrm{II})$ (Melton et al., 2014). In addition, many microorganisms are thought to transfer electrons between their cytoplasmic membranes and extracellular minerals through a network of redox and structural c-type cytochromes (c-Cyts) and flavins (Shi et al., 2016). The redox cycling of Fe during interfacial interactions between $\mathrm{Fe}(\mathrm{III})$-containing minerals and bacteria accelerates the generation of $\mathrm{HO}^{\circ}$ (Page et al., 2013).

The responses of the inhibition activity of $\mathrm{J} 12$ followed the order $\mathrm{Fe}(\mathrm{III})$-containing minerals $>\mathrm{Fe}\left(\mathrm{NO}_{3}\right)_{3}>$ control (Figs. 1 and S9). Intracellular oxidative toxicity also caused by soluble Fe(III) played an important role in the inhibition activity (Schoonen et al., 2006). We deduced that inhibition of $\mathrm{J} 12$ with $\mathrm{Fe}(\mathrm{III})$-containing minerals mainly depends on the coupled effect of soluble Fe, surface Fe(II) and extracellular $\mathrm{HO}^{\circ}$.

\subsection{Inhibition of $\mathrm{J12}$ growth by a free-radical mechanism and its implications for soil carbon storage}

In this study, we proposed a schematic of $\mathrm{Fe}(\mathrm{III})$-containing minerals inhibiting J12 growth through a free-radical mechanism (Fig. 9). Surface Fe(II) is produced from the reduction of $\mathrm{Fe}$ (III) on the surface of $\mathrm{Fe}$ (III)-containing minerals, promoting the production of extracellular $\mathrm{HO}^{*}$ through the Fenton or Fenton-like reactions (Garrido-Ramírez et al., 2010). Soluble $\mathrm{Fe}(\mathrm{II})$ and $\mathrm{Fe}(\mathrm{III})$ released from minerals can pene- trate into the cell membranes, thereby inducing intracellular oxidative damage (Williams et al., 2011). Oxidative damage of $\mathrm{HO}^{\circ}$ may induce the damage of a membrane lipid and cardiolipin that can lead to heterotrophic bacterial inactivation (X. Wang et al., 2017). In soil, heterotrophic bacteria are the main driver of soil carbon decomposition and greenhouse gas emission. As a result, the inactivation of heterotrophic bacteria results in the protection of carbon from microbial degradation. Except for the decomposition of soil organic carbon (SOC), the presence of $\mathrm{HO}^{*}$ can also stabilize $\mathrm{C}$ in soil via a rapid formation of new intermolecular covalent bonds among soil components (Piccolo et al., 2011). Formation of new intermolecular covalent bonds increases the recalcitrance of SOC. In addition, the generation of free radicals may also have indirect effects on J12 growth via substrate availability (Table S4). Substrate availability is improved in the presence of radicals, owing to the depolymerization role of radicals on the complex substrates.

Microbes affect the cycling of SOC, and their products are important components of SOC (Kögel-Knabner, 2002; Kleber and Johnson, 2010; Schmidt et al., 2011; Liang et al., 2017). The mobilized $\mathrm{Fe}$ can be easily transformed into the newly formed reactive $\mathrm{Fe}$ (hydro)oxides (especially poorly crystalline Fe oxides) (Kleber et al., 2005; Yu et al., 2017), which will promote the formation of organo-mineral associations that are chemically more stable (Koegel-Knabner et al., 2008). In this study, we suggest that the soil carbon cycle is partly regulated by $\mathrm{Fe}$ minerals (i) by the formation of organo-mineral complexes (Kögel-Knabner, 2002; Kleber and Johnson, 2010; Schmidt et al., 2011) and (ii) by the bac- 
terial development inhibition. However, it should be noted that NB medium containing casein and meat hydrolysates is only a medium that enables the growth of $\mathrm{J} 12$ in this study, and it is very different from organic matter decomposition or substrates available in soil systems. Further investigation should be conducted to explore the effect of microbe-driven Fenton-like reaction on the storage of SOC in soil system in the future.

\section{Conclusions}

Kaolinite, hematite, goethite and ferrihydrite had a significant inhibitory effect on the growth of Pseudomonas brassicacearum $\mathrm{J} 12$, which was more prominent with a higher concentration, following the order $25 \mathrm{mg} \mathrm{mL}^{-1}>10 \mathrm{mg} \mathrm{mL}^{-1}>5 \mathrm{mg} \mathrm{mL}^{-1}$. In contrast, montmorillonite promoted the growth of $\mathrm{J} 12$, which was independent on its concentration. Compared to $\mathrm{Al}(\mathrm{III})$ containing minerals, $\mathrm{Fe}(\mathrm{III})$-containing minerals promoted more $\mathrm{HO}^{\circ}$ generation and thus increased suppression to J12 via a free-radical mechanism. Furthermore, our results revealed that surface $\mathrm{Fe}$ (II) was produced on the mineral surface that may act as a catalyst, promoting the generation of $\mathrm{HO}^{\bullet}$ rather than soluble Fe. The generation of $\mathrm{HO}^{*}$ by $\mathrm{Fe}(\mathrm{III})$-containing minerals follows the order ferrihydrite $>$ goethite $>$ hematite. In summary, our findings indicate that the inhibition of heterotrophic bacteria with $\mathrm{Fe}(\mathrm{III})$ containing minerals mainly depends on the coupled effect of soluble $\mathrm{Fe}$ and extracellular $\mathrm{HO}^{*}$, which may further contribute to soil carbon storage.

Data availability. Data used in this study are archived by the authors and are available on request.

Supplement. The supplement related to this article is available online at: https://doi.org/10.5194/bg-16-1433-2019-supplement.

Author contributions. GHY proposed the concept, designed the experiments and supervised the project. HYD carried out experimental work. BAG conducted the EPR analysis and interpret the EPR result. HYD, GHY, MU and BAG wrote the paper, and all authors discussed the experiments and final paper.

Competing interests. The authors declare that they have no conflict of interest.

Acknowledgements. We thank the staff for their support at the BL01B beamline of the National Center for Protein Sciences Shanghai (NCPSS) and BL15U1 at Shanghai Synchrotron Radiation Facility (SSRF) for assistance during data collection. This work was funded by the National Key Research and Development Program of China (2017YFD0800803) and the National Natural Science Foundation of China (41671294 and 41371248).

Review statement. This paper was edited by Sébastien Fontaine and reviewed by two anonymous referees.

\section{References}

Amonette, J. E.: Improvements to the quantitative assay of nonrefractory minerals for $\mathrm{Fe}(\mathrm{II})$ and total Fe using 1,10Phenanthroline, Clay. Clay Miner., 46, 51-62, 1998.

Amonette, J. E., Russell, C. K., Carosino, K. A., Robinson, N. L., and Ho, J. T.: Toxicity of Al to desulfovibrio desulfuricans, Appl. Environ. Microbiol., 69, 4057-4066, 2003.

Braunschweig, J., Bosch, J., and Meckenstock, R. U.: Iron oxide nanoparticles in geomicrobiology: from biogeochemistry to bioremediation, New Biotechnol., 30, 793-802, 2013.

Chesworth, W.: Encyclopedia of Soil Science, Springer, Dordrecht, 363-369, 2008.

Cornell, R. M. and Schwertmann, U.: The iron oxides: structure, properties, reactions, occurences and uses, Wiley-VCH Verlag $\mathrm{GmbH} \&$ Co. KGaA, 2003.

Diaz, J. M., Hansel, C. M., Voelker, B. M., Mendes, C. M., Andeer, P. F., and Zhang, T.: Widespread production of extracellular superoxide by heterotrophic bacteria, Science, 340, 1223-1226, 2013.

Garrido-Ramírez, E. G., Theng, B. K. G., and Mora, M. L.: Clays and oxide minerals as catalysts and nanocatalysts in Fenton-like reactions - A review, Appl. Clay Sci., 47, 182-192, 2010.

Georgiou, C. D., Sun, H. J., McKay, C. P., Grintzalis, K., Papapostolou, I., Zisimopoulos, D., Panagiotidis, K. Zhang, G., Koutsopoulou, E., Christidis, G. E., and Margiolaki, I.: Evidence for photochemical production of reactive oxygen species in desert soils, Nat. Commun., 6, 7100, https://doi.org/10.1038/ncomms8100, 2015.

Goodman, B. A., Worasith, N., and Deng, W.: EPR spectra of a new radiation-induced paramagnetic centre in kaolins, Clay Miner., 51, 707-714, 2016.

Grosvenor, A. P., Kobe, B. A., Biesinger, M. C., and McIntyre, N. S.: Investigation of multiplet splitting of Fe $2 p_{X P S}$ spectra and bonding in iron compounds, Surf. Interface Anal., 36, 1564 1574, 2004.

Imlay, J. A.: Pathways of oxidative damage, Annu. Rev. Microbiol., 57, 395-418, 2003.

Jucker, B. A., Harms, H., and Zehnder, A. J. B.: Adhesion of the positively charged bacterium Stenotrophomonas (Xanthomonas) maltophilia 70401 to glass and teflon, J. Bacteri., 178, 54725479, 1996.

Kleber, M. and Johnson, M. G.: Chapter 3 - Advances in Understanding the Molecular Structure of Soil Organic Matter: Implications for Interactions in the Environment, in: Advances in Agronomy, edied by: Donald, L. S., Academic Press, 77-142, 2010.

Kleber, M., Mikutta, R., Torn, M. S., and Jahn, R.: Poorly crystalline mineral phases protect organic matter in acid subsoil horizons, Europ. J. Soil Sci., 56, 717-725, 2005. 
Kögel-Knabner, I.: The macromolecular organic composition of plant and microbial residues as inputs to soil organic matter, Soil Biol. Biochem., 34, 139-162, 2017.

Koegel-Knabner, I., Guggenberger, G., Kleber, M., Kandeler, E., Kalbitz, K., Scheu, S., Eusterhues, K., and Leinweber, P.: Organo-mineral associations in temperate soils: Integrating biology, mineralogy, and organic matter chemistry, J. Plant Nutrit. Soil Sci., 171, 61-82, 2008.

Kwan, W. P. and Voelker, B. M.: Rates of hydroxyl radical generation and organic compound oxidation in mineral-catalyzed Fenton-like systems, Environ. Sci. Technol., 37, 1150-1158, 2003.

Lemire, J. A., Harrison, J. J., and Turner, R. J.: Antimicrobial activity of metals: mechanisms, molecular targets and applications, Nat. Rev. Microbiol., 11, 371-384, 2013.

Li, L., Abe, Y., Nagasawa, Y., Kudo, R., Usui, N., Imai, K., Mashino, T., Mochizuki, M., and Miyata, N.: An HPLC assay of hydroxyl radicals by the hydroxylation reaction of terephthalic acid, Biomed. Chromatogr., 18, 470-474, 2004.

Liang, C., Schimel, J. P., and Jastrow, J. D.: The importance of anabolism in microbial control over soil carbon storage, Nat. Microbiol., 2, 17105, https://doi.org/10.1038/nmicrobiol.2017.105, 2017.

Liu, D., Dong, H., Agrawal, A., Singh, R., Zhang, J., and Wang, H.: Inhibitory effect of clay mineral on methanogenesis by Methanosarcina mazei and Methanothermobacter thermautotrophicus, Appl. Clay Sci., 126, 25-32, 2016.

Londono, S. C., Hartnett, H. E., and Williams, L. B.: Antibacterial activity of aluminum in clay from the Colombian Amazon, Environ. Sci. Technol., 51, 2401-2408, 2017.

Luo, L., Lv, J., Xu, C., and Zhang, S.: Strategy for characterization of distribution and associations of organobromine compounds in soil using synchrotron radiation based spectromicroscopies, Anal. Chem., 86, 11002-11005, 2014.

McMahon, S., Anderson, R. P., Saupe, E. E., and Briggs, D. E. G.: Experimental evidence that clay inhibits bacterial decomposers: Implications for preservation of organic fossils, Geology, 44, 867-870, 2016.

Melton, E. D., Swanner, E. D., Behrens, S., Schmidt, C., and Kappler, A.: The interplay of microbially mediated and abiotic reactions in the biogeochemical Fe cycle, Nat. Rev. Microbiol., 12, 797-808, 2014.

Meunier, A.: Clays, Springer Berlin Heidelberg, New York, 2005.

Morrison, K. D., Misra, R., and Williams, L. B.: Unearthing the antibacterial mechanism of medicinal clay: A geochemical approach to combating antibiotic resistance, Sci. Rep., 6, 19043, https://doi.org/10.1038/srep19043, 2016.

Page, S. E., Kling, G. W., Sander, M., Harrold, K. H., Logan, J. R., McNeill, K., and Cory, R. M.: Dark formation of hydroxyl radical in arctic soil and surface waters, Environ. Sci. Technol., 47, 12860-12867, 2013.

Petigara, B. R., Blough, N. V., and Mignerey, A. C.: Mechanisms of hydrogen peroxide decomposition in soils, Environ. Sci. Technol., 36, 639-645, 2002.

Piccolo, A., Spaccini, R., Nebbioso, A., and Mazzei, P.: Carbon sequestration in soil by in situ catalyzed photo-oxidative polymerization of soil organic matter, Environ. Sci. Technol., 45, 66976702, 2011.
Piña, R. G. and Cervantes, C.: Microbial interactions with aluminium, Biometals, 9, 311-316, 1996.

Polerecky, L., Adam, B., Milucka, J., Musat, N., Vagner, T., and Kuypers, M. M.: Look@ NanoSIMS - a tool for the analysis of nanoSIMS data in environmental microbiology, Environ. Microbiol., 14, 1009-1023, 2012.

Schmidt, M. W., Torn, M. S., Abiven, S., Dittmar, T., Guggenberger, G., Janssens, I. A., Kleber, M., Kogel-Knabner, I., Lehmann, J., Manning, D. A., Nannipieri, P., Rasse, D. P., Weiner, S., and Trumbore, S. E.: Persistence of soil organic matter as an ecosystem property, Nature, 478, 49-56, 2011.

Schoonen, M. A. A., Cohn, C. A., Roemer, E., Laffers, R., Simon, S. R., and O'Riordan, T.: Mineral-induced formation of reactive oxygen species, Rev. Mineral. Geochem., 64, 179-221, 2006.

Schwertmann, U. and Cornell, R. M.: Iron Oxides in the Laboratory: Preparation and characterization, edited by: Schwertmann, U. and Cornell, R. M., Wiley-VCH Verlag GmbH, 121-134, 2007.

Shi, L., Dong, H. L., Yu, H. Q., Reguera, G., Beyenal, H., Lu, A. H., and Fredrickson, J. K.: Extracellular electron transfer mechanisms between microorganisms and minerals, Nat. Rev. Microbiol., 14, 651-662, 2016.

Stohs, S. J. and Bagchi, D.: Oxidative mechanisms in the toxicity of metal-ions, Free Rad. Bio. Med., 18, 321-336, 1995.

Sun, F. S., Li, Y. Q., Wang, X., Chi, Z. L., and Yu, G. H.: Using new hetero-spectral two-dimensional correlation analyses and synchrotron-radiation-based spectromicroscopy to characterize binding of $\mathrm{Cu}$ to soil dissolved organic matter, Environ. Pollut., 223, 457-465, 2017a.

Sun, F. S., Polizzotto, M. L., Guan, D. X., Wu, J., Shen, Q. R., Ran, W., Wang, B. R., and Yu, G. H.: Exploring the interactions and binding sites between $\mathrm{Cd}$ and functional groups in soil using two-dimensional correlation spectroscopy and synchrotron radiation based spectromicroscopies, J. Hazard. Mater., 326, 18-25, 2017b.

Tombácz, E. and Szekeres, M.: Surface charge heterogeneity of kaolinite in aqueous suspension in comparison with montmorillonite, Appl. Clay Sci., 34, 105-124, 2006.

Usman, M., Hanna, K., and Haderlein, S.: Fenton oxidation to remediate PAHs in contaminated soils: A critical review of major limitations and counter-strategies, Sci. Total Environ., 569/570, 179-190, 2016.

Usman, M., Byrne, J. M., Chaudhary, A., Orsetti, S., Hanna, K., Ruby, C., Kappler, A., and Haderlein, S. B.: Magnetite and green rust: Synthesis, properties, and environmental applications of mixed-valent iron minerals, Chem. Rev., 118, 3251-3304, 2018.

Wang, D., Zhao, L., Ma, H., Zhang, H., and Guo, L. H.: Quantitative analysis of reactive oxygen species photogenerated on metal oxide nanoparticles and their bacteria toxicity: The role of superoxide radicals, Environ. Sci. Technol., 51, 10137-10145, 2017.

Wang, X., Dong, H., Zeng, Q., Xia, Q., Zhang, L., and Zhou, Z.: Reduced iron-containing clay minerals as antibacterial agents, Environ. Sci. Technol., 51, 7639-7647, 2017.

Wilke, M., Farges, F., Petit, P. E., Brown, G. E., and Martin, F.: Oxidation state and coordination of Fe in minerals: An Fe $K$ XANES spectroscopic study, Am. Mineral., 286, 714-730, 2001.

Williams, L. B.: Geomimicry: Harnessing the antibacterial action of clays, Clay Miner., 52, 1-24, 2017. 
Williams, L. B. and Haydel, S. E.: Evaluation of the medicinal use of clay minerals as antibacterial agents, Int. Geol. Rev., 52, 745$770,2010$.

Williams, L. B., Haydel, S. E., Jr, R. F. G., and Eberl, D. D.: Chemcial and mineralogical charcteristics of French green clays used for healing, Clay. Clay Miner., 56, 437-452, 2008.

Williams, L. B., Metge, D. W., Eberl, D. D., Harvey, R. W., Turner, A. G., Prapaipong, P., and Poret-Peterson, A. T.: What makes a natural clay antibacterial?- Environ. Sci. Technol., 45, 37683773, 2011.

Wilson, L. A. and Butterfield, N. J.: Sediment effects on the preservation of Burgess Shale-Type compression fossils, Palaios, 29, 145-154, 2014.

Wu, H., Chen, W., Rong, X., Cai, P., Dai, K., and Huang, Q.: Soil colloids and minerals modulate metabolic activity of measured using microcalorimetry, Geomicrobiol. J., 31, 590-596, 2014.
Yamashita, T. and Hayes, P.: Analysis of XPS spectra of $\mathrm{Fe}^{2+}$ and $\mathrm{Fe}^{3+}$ ions in oxide materials, Appl. Surf. Sci., 254, 2441-2449, 2008.

Yu, G. H., Xiao, J., Hu, S. J., Polizzotto, M. L., Zhao, F. J., McGrath, S. P., Li, H., Ran, W., and Shen, Q. R.: Mineral availability as a key regulator of soil carbon storage, Environ. Sci. Technol., 51, 4960-4969, 2017.

Zhou, T., Chen, D., Li, C., Sun, Q., Li, L., Liu, F., Shen, Q., and Shen, B.: Isolation and characterization of Pseudomonas brassicacearum $\mathrm{J} 12$ as an antagonist against ralstonia solanacearum and identification of its antimicrobial components, Microbiol. Res., 167, 388-394, 2012. 